\title{
Safety and Feasibility of Autologous Olfactory Ensheathing Cell and Bone Marrow Mesenchymal Stem Cell Co-transplantation in Chronic Human Spinal Cord Injury: A Clinical Trial
}

\author{
Homa Zamani \\ Tarbiat Modares University Faculty of Medical Sciences \\ Mina Soufizomorrod \\ Tarbiat Modares University Faculty of Medical Sciences \\ Saeed Oraee-Yazdani \\ Shahid Beheshti University of Medical Sciences: Shaheed Beheshti University of Medical Sciences

\section{Dariush Naviafar} \\ Erfan Hospital \\ Mohammadhosein Akhlaghpasand \\ Shahid Beheshti University of Medical Sciences: Shaheed Beheshti University of Medical Sciences

\section{Afsoun Seddighi} \\ Shahid Beheshti University of Medical Sciences \\ Masoud Soleimani ( $\nabla$ soleim_m@modares.ac.ir) \\ Tarbiat Modares University Faculty of Medical Sciences https://orcid.org/0000-0003-1972-7771
}

\section{Research Article}

Keywords: Cell Transplantation, Combined Therapy, Olfactory Ensheathing Cell, Mesenchymal Stem Cell, Spinal Cord Regeneration

Posted Date: April 27th, 2021

DOI: https://doi.org/10.21203/rs.3.rs-435425/v1

License: (c) (i) This work is licensed under a Creative Commons Attribution 4.0 International License. Read Full License

Version of Record: A version of this preprint was published at Spinal Cord on September 9th, 2021. See the published version at https://doi.org/10.1038/s41393-021-00687-5. 


\section{Abstract}

Cell-based therapies are considered as promising strategies for spinal cord regeneration. However, a combinatorial cell therapeutic approach seems more beneficial as it can target various aspects of the injury. Here, we assessed the safety and feasibility of autologous mucosal Olfactory Ensheathing Cell (OEC) and bone marrow Mesenchymal Stem Cell (MSC) co-transplantation in patients with chronic, complete (American Spinal Injury Association (ASIA) classification A) Spinal Cord Injury (SCI). Three patients with the traumatic $\mathrm{SCl}$ of the thoracic level were enrolled. They received autologous OEC and MSC combination through the lumbar puncture. All adverse events and possible functional outcomes were documented performing pre- and post-operative general clinical examination, Magnetic Resonance Imaging (MRI), neurological assessment based on the International Standard of Neurological Classification for $\mathrm{SCl}$ (ISNCSCI), and functional evaluation using Spinal Cord Independence Measure version III (SCIM III). No serious safety issue was recorded during the two years of follow-up. MRI findings remained unchanged with no neoplastic tissue formation. ASIA impairment scale improved from A to B in one of the participants. SCIM III evaluation also showed some degrees of progress in this patient's quality of life. The two other patients had negligible or no improvement in their sensory scores without any changes in the ASIA impairment scale and SCIM III scores. No motor recovery was observed in any of the participants. Overall, this two-year trial was not associated with any adverse findings, which may suggest the safety of autologous OEC and bone marrow MSC combination for the treatment of human SCl.

This study was registered at the Iranian Registry of Clinical Trials (IRCT registration number: IRCT20160110025930N2/ registration date: 2018-09-29).

\section{Introduction}

The limited regenerative capacity of the spinal cord often confronts people affected by the Spinal Cord Injury (SCI) with permanent disability and dependency to their families and society (Mehrabi et al. 2013). It has been a while that cell replacement therapies have emerged as promising strategies for SCl treatment, among them Olfactory Ensheathing Cells (OECs) and Mesenchymal Stem Cells (MSCs) are considered as two of the most encouraging candidates (Anna et al. 2017).

OECs are a particular type of macroglia residing in both peripheral (olfactory mucosa and olfactory nerve) and central (olfactory bulb) parts of the olfactory system and support the continuous neurogenesis of the olfactory neurons throughout life (Chou et al. 2014). The high regenerative potential of OECs like the stimulation of axonal regrowth, re-myelination, and guidance across the lesion is the rationale behind the extensive use of these cells in the experimental models of SCI (Lankford et al. 2008; Gilmour et al. 2020).

Bone marrow MSCs also possess different regenerative qualities that make them beneficial for spinal cord repair. They can differentiate into various cell types and secrete trophic factors that promote axonal growth while lacking tumorigenicity. Besides, through their immunomodulatory, anti-inflammatory, and anti-apoptotic effects, MSCs can play a vital neuroprotective role within the injured tissue and provide axons with a permissive environment for their regeneration (Taran et al. 2014).

Many clinical trials have been conducted to assess the safety and functional recovery following OEC or MSC transplantation alone in patients with traumatic SCI (Tabakow et al. 2013; Mendonça et al. 2014). However, concerning the progressive, multifactorial nature of this injury, it seems that applying an appropriate combination of such highly potent cells may lead to better outcomes (Griffin and Bradke 2020). The safety and efficacy of some combination therapies have been documented in preclinical models of SCl (Zhang et al. 2017). Several clinical studies have also been designed to demonstrate the feasibility of this approach for spinal cord regeneration (Oraee-Yazdani et al. 2013; Chen et al. 2014). In the present study, we evaluated the safety and feasibility of autologous mucosal OEC and bone marrow MSC co-transplantation into patients with chronic, complete, traumatic SCI.

\section{Methods}

\section{Study design}

All of the clinical procedures including olfactory mucosa biopsy, bone marrow aspiration, and cell transplantation were performed in Shohada Tajrish Hospital, affiliated with Shahid Beheshti University of Medical Sciences. Inclusion criteria were having a thoracic 
$\mathrm{SCl}$, complete loss of sensory and motor function below the site of injury (American Spinal Injury Association (ASIA) grade A), at least 6 months post-injury (chronic phase), male or female aged 18 to 70 years, and suffering from no mental disturbance. Exclusion criteria included having severe medical complications or other lesions of the nervous system, spinal stenosis or compression, muscle atrophy, and clinically significant chronic sinusitis or polyps of nasal cavities.

Three patients were enrolled in this trial, all of whom had a chronic, thoracic lesion that resulted either from a road traffic accident or falling from a height. The preoperative neurological evaluation of the patients showed a complete paralysis that was persistent over at least 6 months before the surgery. All three patients had been undergone spinal decompression and fixation surgery at the time of injury. Further assessments to verify eligibility showed no impediment for the mucosal biopsy, bone marrow aspiration, and subsequent cell transplantation (Table 1).

All of the participants went through a regular rehabilitation program started 6 months before the operation and continued until discharge. This scheduled program included physical therapy strategies with a great focus on overground and treadmill locomotor training activities.

\section{Olfactory mucosa biopsy, bone marrow aspiration, and cell isolation}

To obtain mucosal biopsies under general anesthesia, the patients were hospitalized. They were placed in a supine position in the operation room. After irrigating and disinfecting the nasal cavities, the biopsy was harvested from the area of superior turbinate using the endoscope. The collected specimens were placed in a cold Hanks' Balanced Salt Solution (HBSS, Sigma-Aldrich, St. Louis, USA) consisting of $100 \mathrm{U} / \mathrm{ml}$ penicillin and $100 \mu \mathrm{g} / \mathrm{ml}$ streptomycin (Gibco, Grand Island, USA) and transferred to the cell culture laboratory in a sterile, sealed container. All the next steps were carried out in a class $\mathrm{C}$ current good manufacturing practice (cGMP) facility with a class 100 biosafety cabinet under aseptic processing. The isolation of OECs was done according to a protocol described previously (Tabakow et al. 2013). Briefly, the tissue fragments were digested with a $2.4 \mathrm{U} / \mathrm{ml}$ dispase II solution (SigmaAldrich). After removing the olfactory epithelium, the lamina propria was cut into small pieces and treated with a $5 \mathrm{mg} / \mathrm{ml}$ collagenase $\mathrm{H}$ solution (Sigma-Aldrich), followed by centrifugation and culturing of the cells.

Bone marrow $(100 \mathrm{ml})$ was aspirated from the posterior superior iliac spine of the iliac crest. Based on our previously described method (Oraee-Yazdani et al. 2013), MSC isolation was done using a 1:3 volume of Ficoll solution (1.077 g/L, Sigma-Aldrich). The biphasic prepared sample was centrifuged, and the mononuclear cell layer was separated carefully. After performing three washing steps with HBSS, these cells were also cultured in the appropriate culture conditions.

\section{In-process and final quality control tests}

Cell characterization. The characterization of OECs was performed using both S100 and Glial Fibrillary Acidic Protein (GFAP) immunocytochemical staining. The isolated cells were fixed and permeabilized with $4 \%$ paraformaldehyde and $0.1 \%$ Triton $X-100$ (both Sigma-Aldrich), respectively. The blocking step was done with $10 \%$ goat serum (Gibco), followed by incubation with anti-S100 or anti-GFAP (both Santa Cruz Biotechnology, CA, USA) antibody at $4^{\circ \mathrm{C}}$ overnight. The samples were then incubated with a suitable horseradish peroxidase-conjugated secondary antibody (Sigma-Aldrich) for 1 hour and finally exposed to 3, 3'-diaminobenzidine (Sigma-Aldrich) to produce the chromogenic reaction. Hematoxylin (Sigma-Aldrich) was applied for nuclear counter-staining, and cell visualization was carried out through a light microscope.

To confirm the identity of bone marrow-derived cells as MSCs, they were subjected to both flow cytometric analysis of verification markers and differentiation capacity toward adipogenic and osteoblastic lineages (Oraee-Yazdani et al. 2013).

Sterility test and gram stain. The cells were regularly assessed microscopically to confirm their normal growth and the lack of visible contaminations. A direct inoculation sterility test was done every 5 days and also from the final harvested product (Khuu et al. 2006). In brief, a sample was taken from the supernatant of the cultured cell and injected into two microbial culture tubes containing Tryptic Soy Broth and Fluid Thioglycollate Medium (TSB, FTM, both Merck, Darmstadt, Germany). The test tubes were incubated for 14 days at $25^{\circ \mathrm{C}}$ and $35^{\circ \mathrm{C}}$ for TSB and FTM, respectively. Before the transplantation, the standard Gram staining was performed as well on the final cell suspension to verify the absence of contaminating organisms. 
Viability assay. A Propidium lodide $(\mathrm{PI})$ stating was carried out on the final cell mixture before the operation. Following the sample preparation, $1 \times 10^{4}$ cells $/ 100 \mu \mathrm{l}$ were mixed with a 5-10 $\mu \mathrm{l} \mathrm{PI} \mathrm{fluorescent} \mathrm{agent} \mathrm{(Sigma-Aldrich).} \mathrm{The} \mathrm{sample} \mathrm{was} \mathrm{then} \mathrm{incubated} \mathrm{in}$ the dark for $1 \mathrm{~min}$ and finally analyzed by FACS Calibur flow cytometer and Flowjo software.

Cytogenetic analysis. The cytogenetic stability of the cultured cells was studied using the standard GTG-banding technique. The cells were delivered to the cytogenetic department of Children's Medical Center and harvested for the conventional karyotype examination.

\section{Cell transplantation}

The cells were separately trypsinized and prepared for transplantation. They were mixed in a ratio of 1:1 of OEC: MSC in $2 \mathrm{ml}$ injectable saline solution ( $0.9 \%$ ) at a final concentration of $15 \times 10^{6}$ cells per $\mathrm{ml}$. Under sterile conditions, the intrathecal injection of the cell mixture was carried out according to our previous study (Oraee-Yazdani et al. 2016). Briefly, the patients were hospitalized and placed in the operating room in a lateral position. After aseptic preparation, the sample was slowly injected into the subarachnoid space of the L4/L5 level through the lumbar puncture using the spinal needle $24 \mathrm{G}$. The needle was kept in place for one additional minute to avoid leakage.

\section{Pre- and post-operative evaluations}

The patients were monitored regularly to record the vital signs and any adverse events based on the Common Terminology Criteria for Adverse Events (CTCAE) version 5.0 guideline. The pre-operative Magnetic Resonance Imaging (MRI) scans were carefully analyzed and compared with the ones taken 12 and 24 months post-surgery to track the radiological changes of the spinal cord and its surrounding tissue. To follow the neurological status and functional recovery of the patients, the International Standard of Neurological Classification for Spinal Cord Injury (ISNCSCI) sensory and motor scoring system and the Spinal Cord Independence Measure (SCIM) version III scale were respectively evaluated before and after surgery at 6-month intervals up to 24 months. An electromyography test was carried out when the patients claimed any improvements in their motor activity to confirm that the reported muscle contraction is voluntary.

\section{Results}

\section{Cell culture and quality control tests}

The cells isolated from the three patients were grown in culture for three to four weeks until they were ready for transplantation. They all were in a good growth state and had a normal and healthy appearance. The olfactory-derived cells were positive for both S100 and GFAP identification markers of OEC (Fig.1a). The differentiation capacity of the cultured MSCs toward the osteoblastic and adipogenic lineages was also confirmed (Fig.1b), and they were found to be positive for CD 73, 90, and 105 and negative for CD 34 and 45 cell surface antigens (Fig.1C).

The visual inspection of in-process and final sterility tests didn't show any turbidity indicating microbial growth throughout the culture. The Gram stain also didn't detect the presence of microbial contaminants in the final product (data not shown).

The pre-operative PI viability assessment of the OEC/MSC mixture demonstrated at least $92 \%$ alive cells, which showed their potential suitability for transplantation (Fig.1d). Additionally, no numerical or structural chromosome abnormality was indicated in the cytogenetic analysis of the cells (Fig.1e).

\section{Safety assessment}

Clinical examination. No mortality or severe adverse event occurred in the patients within the follow-up period. No evidence of fever, hypersensitivity, inflammation, meningitis, or other allergic or infectious diseases that could be attributed to the cell transplantation was observed. None of the transplant recipients showed the deterioration of their neurological condition. Two of the participants (patients 2 and 3) reported either the onset or increase of neuropathic pain after transplantation that was alleviated by receiving gabapentin and vitamin B1. Appropriate antispasmodic drugs were prescribed for patient 2 with an increased spasm frequency in the lower extremity muscles. One month after transplantation, patient 1 had a bronchial infection that was not related to the 
performed intervention. Patients 2 and 3 also complained of a mild headache that started on the day following mucosal biopsy and lasted for about two days. All three patients experienced mild, temporary hyposmia that spontaneously resolved after 1-2 weeks. A summary of the observed adverse events is provided in Table 2.

Radiology. Some of the worst effects were detected on the visibility of images in all of the patients who had been undergone spinal instrumentation. However, the radiological assessments didn't reveal any changes in the spinal cord and its surrounding parenchyma with no evidence of neoplastic tissue formation. MRI findings also showed no excessive spinal compression (Fig.2).

\section{Evaluation of neurological, functional, and other subjective changes}

The patients' neurological and functional status at enrollment remained unchanged until the time of surgery. No improvement nor deterioration was seen in the sensory and motor function of patient 1 over the two years of observation. Patient 3, however, had a negligible improvement in his ASIA sensory scale with a 2-point increase in the light touch and pinprick sensation at both sites but no perianal sensation. The most promising result was observed in patient 2 . She had significant improvement in her sensory score that was initially detected 6 months after transplantation and continued progressively. The sacral exam showed the presence of bilateral S4-5 and deep anal pressure sensation at this patient one year post-surgery. The ASIA sensory score increased 9 points for each of light touch and pinprick scales at both sides and reached the total amount of 46 at the end of the study. She had changes in her lower extremity motor function, but no voluntary muscle contraction was recorded in the electromyography test of this patient (data not shown). Based on these results, the ASIA classification of patient 2 altered from A to B. In contrast, patients 1 and 3 had no change in their ASIA impairment scale.

Monitoring the functional changes, using the SCIM III scale, also revealed no progress in the life quality of patients 1 and 3 . On the other hand, some abilities of patient 2 including self-care activities and bed mobility improved compared to the pre-operative time. She gained more independence in her daily life with a 6-point elevation in her total SCIM III score. Table 3 represents the results of the patients' neurological and functional assessments.

The participants also reported some other subjective changes during the study. Two of them (patients 2 and 3 ) declared having urination sensation. Patient 2 reported a feeling of defecation as well. None of the patients regained their complete bladder or bowel sphincter control. From the aspect of trunk movements, stability, and trunk equilibration in the sitting and standing positions, more improvement was reported by patients 2 and 3 (Table 4).

\section{Discussion}

Many intrinsic and extrinsic growth inhibitory factors are involved in the progression of $\mathrm{SCl}$ and its lack of response to current treatments. It seems that implementing a combinatorial strategy would be more beneficial than a single therapy as it can address more aspects of the disease (Griffin and Bradke 2020).

To date, different approaches have been applied to combine individual SCI treatment options. One of the recent avenues of research in this area has focused on the transplantation of regenerative cells together to repair different pathological barriers and also take advantage of the synergistic effects of these cells. The practicality of this new scenario using various cell combinations has been tested in some preclinical and clinical studies and reported the safety and some degrees of efficacy for them (Chen et al. 2014; Oraee-Yazdani et al. 2016; Hosseini et al. 2018). However, there is still a long way to discover the most efficient combinatory cell-based design for human SCl.

Because of their physical support, expressing some growth and guidance factors, phagocytic function, and having more efficiency for migration and integration with astrocytes than Schwann cells, OECs are increasingly taking into account as attractive tools for the repair of the injured spinal cord (Gilmour et al. 2020). MSCs have also shown more benefits over other stem cell types since they are easily accessible from varied sources with no ethical issue. They have this capacity to highly proliferate and differentiate toward both neuronal and non-neuronal lineages while they are generally safe and less likely to produce tumors (Cofano et al. 2019).

The combined application of MSC and OEC for SCl treatment has been previously examined in several veterinary trials. Deng et al. showed that compared to the singular therapeutic strategy, the co-grafting of human bone marrow stem cell and olfactory

Page 5/14 
ensheathing glia to a thoracic $\mathrm{SCl}$ rat model was associated with better histologic, electrophysiologic, and functional outcomes (Deng et al. 2008). Another study in 2015 also reported more functional recovery in rats treated with OEC/MSC combination than using either cell alone and justified it by the enhanced anti-apoptotic effect of this cell mixture (Wu et al. 2015). Moreover, the coadministration of these cells into the $\mathrm{SCl}$ rats resulted in the restoration of motor function and reduced the inflammatory cells in the injured area (Gomes et al. 2018). These encouraging results prompted us to investigate the translatability of this combination therapy into human SCl.

Both the olfactory bulb and olfactory mucosa are used to harvest OECs for autologous transplantation. However, mucosal OECs are considered the preferable type of these cells for human application as the isolation of bulbar OECs requires performing a more invasive surgery while the olfactory mucosa is easily accessible (Reshamwala et al. 2020). As a result, in this study, we used the olfactory mucosa as our source of OEC. Except for a mechanical and enzymatic dissociation step, the cells didn't undergo any further purification. The reason was that according to some previous studies a heterogeneous population of OECs may have more potential for repairing different aspects of such neural defects (Barnett and Chang 2004).

We decided to use the lumbar intrathecal route of administration as our mode of cell delivery since it is considered a less invasive method than the direct parenchymal injection (Paul et al. 2009). Besides, studies have shown that the cells injected into the cerebral spinal fluid by the lumbar puncture are better survived and delivered to the spread sites of injury (Satake et al. 2004). More progress was also achieved in the ISNCSCI scores of the patients by injecting the Schwann cell and MSC through the cerebral spinal fluid than the direct injection into the injured area (Oraee-Yazdani et al. 2013; Oraee-Yazdani et al. 2016).

Our primary outcome measure in the designation of this clinical study was to evaluate the safety of autologous mucosal OEC and bone marrow MSC co-transplantation in patients with complete, chronic SCl. Altogether, no radiological or systemic adverse event was detected in any of the participants, which may suggest the safety of this combinational cell therapy approach for human SCl. All of the recorded negative findings were classified as mild (grade I) to moderate (grade II) in terms of severity. Headache and neuropathic pain were the most prevalent adverse events. The headache was transient and likely relevant to the biopsy from the nasal mucosa, although the previous experiments did not report such a negative event ( $\mathrm{Li}$ et al. $\underline{2015}$ ). Two of the three participants experienced the initiation or intensification of neuropathic pain. Researches show that in addition to the nerve injury this medical condition can occur as a consequence of cell transplantation (Macias et al. 2006). According to these studies, both single and combinatorial cell therapeutic interventions can increase the risk of neuropathic pain, and its incidence has been reported about one-third to one-half of the total number of transplant recipients (Lima et al. 2006; Oraee-Yazdani et al. 2013; Oraee-Yazdani et al. 2016). However, due to the small sample size of our non-controlled survey, we cannot suggest that our cell therapy method may be associated with a higher risk of neuropathic pain.

To assess the safety in this phase I trial under the International Campaign for Cure of spinal cord Paralysis panel guidelines, we selected complete thoracic SCl patients with no improvement in the neurologic or functional scales after injury (Tuszynski et al. 2007). Regarding our determined criteria, only three volunteers were known eligible for enrolment in this pilot study, which is comparable with some of the previous phase I cell-based trials (Feron et al. 2005; Tabakow et al. 2013). Additionally, we did not have randomly allocated control groups since it is not considered a necessary item for phase I clinical studies (Lammertse et al. 2007).

The cell injections were done between 23 and 75 months following $\mathrm{SCl}$ when all of the participants had stable neurologic conditions, and the possibility of any nonintervention-related recovery was almost zero (Fawcett et al. 2007). One of our patients had a significant response to this treatment so that her quality of life somewhat improved and her ASIA classification changed from A (complete) to B (motor complete). Although rehabilitation could have been helpful in the neurological recovery of this patient, it cannot be regarded as the main cause of improvement because she had no change in her ISNCSCI and SCIM scores during the 6-month pre-operative rehabilitation program. These results may offer a similar benefit for the OEC/MSC combination compared to the co-transplantation of Schwann cells and MSCs that led to an improvement in ISNCSCI scores and a change in the ASIA impairment scale in one of the participants (Oraee-Yazdani et al. 2016). Nevertheless, the small sample size of this safetyphase trial prevents us from commenting on these findings with more certainty.

The promising subjective results of this study were also similar to the reports of our previous Schwann cell/ MSC combination therapies (Oraee-Yazdani et al. 2013; Oraee-Yazdani et al. 2016). These improvements, however, were associated with some degrees

Page 6/14 
of progress in the motion scores of patient 2, which more emphasize the significance of the obtained favorable results. On the other hand, no progress was recorded in the total SCIM score of patient 3, and despite reporting urinary or defecation sensation, the bladder or bowel sphincter management scores were unchanged, which may be attributed to both severity and chronicity of the injury and the stable condition of the patients.

Based on the obtained results and the numerous evidence on the outstanding regenerative properties of OECs and MSCs, the simultaneous application of these cells in human $\mathrm{SCl}$ seems justifiable. Owing to the use of the great regenerative potential of both cells, this combination can therefore be acknowledged as one of the most encouraging treatments of choice to overcome various obstacles in the functional restoration of the damaged spinal cord.

\section{Conclusion}

Overall, this study proposes the short- and longer-term safety for the concurrent administration of autologous mucosal OEC and bone marrow MSC into patients with chronic, complete SCl. No serious adverse reaction relating to this therapy was seen during at least two years of follow-up, which may suggest it as a safe treatment procedure. However, due to the various limitations of the present study such as its small number of participants, lacking control groups, and the inadequacy of the objective measures, we cannot prove the efficacy of this treatment approach. Therefore, it is required to design randomized controlled phase II trials with larger sample sizes to further evaluate its safety and true efficacy in human SCl.

\section{Declarations}

\section{Funding}

This work was supported by the research grant from the Faculty of Medical Sciences, Tarbiat Modares University (Med-75939); and in part by the funding from the Organ, Tissue, and Cell Processing Center, Tehran, Iran.

\section{Conflicts of interest}

The authors declare that they have no conflict of interest.

\section{Availability of data and material}

There were no data to deposit.

\section{Code availability}

Not applicable

\section{Authors' Contributions}

Masoud Soleimani, Mina Soufizomorrod, Saeed Oraee-Yazdani, Dariush Naviafar, and Homa Zamani conceptualized and designed the study. Data collection and analysis were performed by Homa Zamani and Mohammadhosein Akhlaghpasand. The first draft of the manuscript was written by Homa Zamani, and all of the authors commented on the previous versions of it. All authors read and approved the final manuscript.

\section{Ethics approval}

This study was designed in accordance with the 1964 Declaration of Helsinki and was approved by the Ethics in Medical Research Committee of Tarbiat Modares University (IR.TMU.REC.1396.737).

\section{Consent to participate}

All of the procedures were performed after a written informed consent including the detailed description of all of the experimental processes, the probable adverse events, and the potential for no benefit was obtained from each of the patients. 


\section{References}

1. Anna Z, Katarzyna J-W, Joanna C, Barczewska M, Joanna W, Wojciech M (2017) Therapeutic potential of olfactory ensheathing cells and mesenchymal stem cells in spinal cord injuries. Stem Cells Int. 2017. https://doi.org/10.1155/2017/3978595

2. Barnett SC, Chang L (2004) Olfactory ensheathing cells and CNS repair: going solo or in need of a friend? Trends Neurosci 27(1):54-60. https://doi.org/10.1016/j.tins.2003.10.011

3. Chen L, Huang H, Xi H, Zhang F, Liu Y, Chen D, Xiao J (2014) A prospective randomized double-blind clinical trial using a combination of olfactory ensheathing cells and Schwann cells for the treatment of chronic complete spinal cord injuries. Cell Transplant 23(1_suppl):35-44. https://doi.org/10.3727/096368914X685014

4. Chou R-H, Lu C-Y, Wei-Lee FJ-R, Yu Y-L, Shyu W-C (2014) The potential therapeutic applications of olfactory ensheathing cells in regenerative medicine. Cell Transplant 23(4-5):567-571. https://doi.org/10.3727/096368914X678508

5. Cofano F, Boido M, Monticelli M, Zenga F, Ducati A, Vercelli A, Garbossa D (2019) Mesenchymal stem cells for spinal cord injury: current options, limitations, and future of cell therapy. Int J Mol Sci 20(11):2698. https://doi.org/10.3390/ijms20112698

6. Deng Y, Liu Y, Zhu W, Bi X, Wang Y, Ye M, Zhou G (2008) The co-transplantation of human bone marrow stromal cells and embryo olfactory ensheathing cells as a new approach to treat spinal cord injury in a rat model. Cytotherapy 10(6):551-564. https://doi.org/10.1080/14653240802165673

7. Fawcett J, Curt A, Steeves J, Coleman W, Tuszynski M, Lammertse D, Bartlett P, Blight A, Dietz V, Ditunno J (2007) Guidelines for the conduct of clinical trials for spinal cord injury as developed by the ICCP panel: spontaneous recovery after spinal cord injury and statistical power needed for therapeutic clinical trials. Spinal Cord 45(3):190-205.

https://doi.org/10.1038/sj.sc.3102007

8. Feron F, Perry C, Cochrane J, Licina P, Nowitzke A, Urquhart S, Geraghty T, Mackay-Sim A (2005) Autologous olfactory ensheathing cell transplantation in human spinal cord injury. Brain 128(12):2951-2960.

https://doi.org/10.1093/brain/awh657

9. Gilmour AD, Reshamwala R, Wright AA, Ekberg JA, St John JA (2020) Optimizing olfactory ensheathing cell transplantation for spinal cord injury repair. J Neurotrauma 37(5):817-829. https://doi.org/10.1089/neu.2019.6939

10. Gomes ED, Mendes SS, Assunção-Silva RC, Teixeira FG, Pires AO, Anjo SI, Manadas B, Leite-Almeida H, Gimble JM, Sousa N (2018) Co-transplantation of adipose tissue-derived stromal cells and olfactory ensheathing cells for spinal cord injury repair. Stem Cells 36(5):696-708. https://doi.org/10.1002/stem.2785

11. Griffin JM, Bradke F (2020) Therapeutic repair for spinal cord injury: combinatory approaches to address a multifaceted problem. EMBO Mol Med 12(3):e11505. https://doi.org/10.15252/emmm.201911505

12. Hosseini SM, Sani M, Haider KH, Dorvash M, Ziaee SM, Karimi A, Namavar MR (2018) Concomitant use of mesenchymal stem cells and neural stem cells for treatment of spinal cord injury: A combo cell therapy approach. Neurosci Lett 668:138-146. https://doi.org/10.1016/j.neulet.2018.01.008

13. Khuu HM, Patel N, Carter CS, Murray PR, Read EJ (2006) Sterility testing of cell therapy products: parallel comparison of automated methods with a CFR-compliant method. Transfusion 46(12):2071-2082. https://doi.org/10.1111/j.15372995.2006.01041.x

14. Lammertse D, Tuszynski M, Steeves J, Curt A, Fawcett J, Rask C, Ditunno J, Fehlings M, Guest JD, Ellaway P (2007) Guidelines for the conduct of clinical trials for spinal cord injury as developed by the ICCP panel: clinical trial design. Spinal Cord 45(3):232-242. https://doi.org/10.1038/sj.sc.3102010

15. Lankford KL, Sasaki M, Radtke C, Kocsis JD (2008) Olfactory ensheathing cells exhibit unique migratory, phagocytic, and myelinating properties in the X-irradiated spinal cord not shared by Schwann cells. Glia 56(15):1664-1678. https://doi.org/10.1002/glia.20718

16. Li L, Adnan H, Xu B, Wang J, Wang C, Li F, Tang K (2015) Effects of transplantation of olfactory ensheathing cells in chronic spinal cord injury: a systematic review and meta-analysis. Eur Spine J 24(5):919-930. https://doi.org/10.1007/s00586-0143416-6 
17. Lima C, Pratas-Vital J, Escada P, Hasse-Ferreira A, Capucho C, Peduzzi JD (2006) Olfactory mucosa autografts in human spinal cord injury: a pilot clinical study. J Spinal Cord Med 29(3):191-203. https://doi.org/10.1080/10790268.2006.11753874

18. Macias MY, Syring MB, Pizzi MA, Crowe MJ, Alexanian AR, Kurpad SN (2006) Pain with no gain: allodynia following neural stem cell transplantation in spinal cord injury. Exp Neurol 201(2):335-348. https://doi.org/10.1016/j.expneurol.2006.04.035

19. Mehrabi S, Eftekhari S, Moradi F, Delaviz H, Pourheidar B, Azizi M, Zendehdel A, Shahbazi A, Joghataei MT (2013) Cell therapy in spinal cord injury: a mini-reivew. Basic Clin Neurosci 4(2):172-176

20. Mendonça MVP, Larocca TF, de Freitas Souza BS, Villarreal CF, Silva LFM, Matos AC, Novaes MA, Bahia CMP, Martinez ACdOM, Kaneto CM (2014) Safety and neurological assessments after autologous transplantation of bone marrow mesenchymal stem cells in subjects with chronic spinal cord injury. Stem Cell Res Ther 5(6):126. https://doi.org/10.1186/scrt516

21. Oraee-Yazdani S, Hafizi M, Zali A-R, Atashi A, Ashrafi F, Seddighi A-S, Soleimani M (2013) Safety and possible outcome assessment of autologous Schwann cell and bone marrow mesenchymal stromal cell co-transplantation for treatment of patients with chronic spinal cord injury. Cytotherapy 15(7):782-791. https://doi.org/10.1016/j.jcyt.2013.03.012

22. Oraee-Yazdani S, Hafizi M, Atashi A, Ashrafi F, Seddighi A, Hashemi S, Seddighi A, Soleimani M, Zali A (2016) Cotransplantation of autologous bone marrow mesenchymal stem cells and Schwann cells through cerebral spinal fluid for the treatment of patients with chronic spinal cord injury: safety and possible outcome. Spinal Cord 54(2):102-109. https://doi.org/10.1038/sc.2015.142

23. Paul C, Samdani AF, Betz RR, Fischer I, Neuhuber B (2009) Grafting of human bone marrow stromal cells into spinal cord injury: a comparison of delivery methods. Spine 34(4):328-334. https://doi.org/10.1097/BRS.0b013e31819403ce

24. Reshamwala R, Shah M, John JS, Ekberg J (2020) The link between olfactory ensheathing cell survival and spinal cord injury repair: a commentary on common limitations of contemporary research. Neural Regen Res 15(10):1848-1849. https://doi.org/10.4103/1673-5374.280310

25. Satake K, Lou J, Lenke LG (2004) Migration of mesenchymal stem cells through cerebrospinal fluid into injured spinal cord tissue. Spine 29(18):1971-1979. https://doi.org/10.1097/01.brs.0000138273.02820.0a

26. Tabakow P, Jarmundowicz W, Czapiga B, Fortuna W, Miedzybrodzki R, Czyz M, Huber J, Szarek D, Okurowski S, Szewczyk P (2013) Transplantation of autologous olfactory ensheathing cells in complete human spinal cord injury. Cell Transplant 22(9):1591-1612. https://doi.org/10.3727/096368912X663532

27. Taran R, Mamidi MK, Singh G, Dutta S, Parhar IS, John JP, Bhonde R, Pal R, Das AK (2014) In vitro and in vivo neurogenic potential of mesenchymal stem cells isolated from different sources. J Biosci 39(1):157-169. https://doi.org/10.1007/s12038013-9409-5

28. Tuszynski M, Steeves J, Fawcett J, Lammertse D, Kalichman M, Rask C, Curt A, Ditunno J, Fehlings M, Guest JD (2007) Guidelines for the conduct of clinical trials for spinal cord injury as developed by the ICCP Panel: clinical trial inclusion/exclusion criteria and ethics. Spinal Cord 45(3):222-231. https://doi.org/10.1038/sj.sc.3102009

29. Wu S, Cui G, Shao H, Du Z, Ng JC, Peng C (2015) The cotransplantation of olfactory ensheathing cells with bone marrow mesenchymal stem cells exerts antiapoptotic effects in adult rats after spinal cord injury. Stem Cells Int. 2015. https://doi.org/10.1155/2015/516215

30. Zhang J, Chen H, Duan Z, Chen K, Liu Z, Zhang L, Yao D, Li B (2017) The effects of co-transplantation of olfactory ensheathing cells and schwann cells on local inflammation environment in the contused spinal cord of rats. Mol Neurobiol 54(2):943-953. https://doi.org/10.1007/s12035-016-9709-5

\section{Tables}

Table 1. Demographic and clinical features of the patients 


\begin{tabular}{|llllllll|}
\hline $\begin{array}{l}\text { Follow up } \\
\text { (month) }\end{array}$ & $\begin{array}{l}\text { ASIA } \\
\text { classification }\end{array}$ & $\begin{array}{l}\text { Time from } \\
\text { SCl (month) }\end{array}$ & $\begin{array}{l}\text { Zone of partial } \\
\text { preservation }\end{array}$ & $\begin{array}{l}\text { Vertebral level } \\
\text { of injury }\end{array}$ & $\begin{array}{l}\text { Cause of } \\
\text { injury }\end{array}$ & $\begin{array}{l}\text { Age } \\
\text { (year) }\end{array}$ & $\begin{array}{c}\text { Sex } \\
\text { Patient } \\
\text { number }\end{array}$ \\
\hline 27 & A & 52 & T10 & T10 & $\begin{array}{l}\text { Road traffic } \\
\text { accident }\end{array}$ & 27 & M \\
\hline 25 & A & 23 & T12 & T11 & $\begin{array}{l}\text { Falling from } \\
\text { height }\end{array}$ & 66 & F \\
\hline 24 & A & 75 & T12 & T12 & $\begin{array}{l}\text { Road traffic } \\
\text { accident }\end{array}$ & 26 & M \\
\hline
\end{tabular}

Abbreviations: M, male; F, female; SCl, spinal cord injury; ASIA, American spinal cord injury association

Table 2. The observed adverse events following the olfactory mucosa biopsy and cell transplantation based on CTCAE version 5.0

\begin{tabular}{|c|c|c|c|c|c|c|}
\hline $\begin{array}{l}\text { Patient } \\
\text { number }\end{array}$ & $\begin{array}{l}\text { Number of } A E(\% \\
\text { respect to total } A E)\end{array}$ & $\begin{array}{l}\text { CTCAE } \\
\text { term }\end{array}$ & $\begin{array}{l}\text { System } \\
\text { organ class }\end{array}$ & $\begin{array}{l}\text { Occurrence }(+) \text { or } \\
\text { exacerbation }(\uparrow) \text { of } \\
\mathrm{AE}\end{array}$ & $\begin{array}{l}\text { Causal link with } \\
\text { OEC/MSC co- } \\
\text { administration }\end{array}$ & Grade $^{a}$ \\
\hline 1 & $1(16.6 \%)$ & $\begin{array}{l}\text { Bronchial } \\
\text { infection }\end{array}$ & $\begin{array}{l}\text { Infections and } \\
\text { infestations }\end{array}$ & + & Not related & II \\
\hline \multirow[t]{3}{*}{2} & $3(50 \%)$ & Headache & $\begin{array}{l}\text { Nervous } \\
\text { system } \\
\text { disorders }\end{array}$ & + & Probable & I \\
\hline & & Neuralgia ${ }^{b}$ & $\begin{array}{l}\text { Nervous } \\
\text { system } \\
\text { disorders }\end{array}$ & $\uparrow$ & Probable & II \\
\hline & & Spasticity & $\begin{array}{l}\text { Nervous } \\
\text { system } \\
\text { disorders }\end{array}$ & $\uparrow$ & Probable & II \\
\hline \multirow[t]{2}{*}{3} & $2(33.3 \%)$ & Headache & $\begin{array}{l}\text { Nervous } \\
\text { system } \\
\text { disorders }\end{array}$ & + & Probable & I \\
\hline & & Neuralgia & $\begin{array}{l}\text { Nervous } \\
\text { system } \\
\text { disorders }\end{array}$ & + & Probable & I \\
\hline
\end{tabular}

Abbreviations: CTCAE, common terminology criteria for adverse events; AE, adverse event; OEC, olfactory ensheathing cell; MSC, mesenchymal stem cell

a Severity of the AE. Grade I: Mild; intervention not indicated. Grade II: Moderate; minimal, local, or noninvasive intervention indicated.

b Neuropathic pain

Table 3. Detailed neurological and functional examinations of the patients before and after cell transplantation 


\begin{tabular}{|c|c|c|c|c|c|c|}
\hline $\begin{array}{l}\text { Variable } \\
\text { name }\end{array}$ & $\begin{array}{l}6 \text { Months } \\
\text { before } \\
\text { transplantation }\end{array}$ & $\begin{array}{l}\text { At the time of } \\
\text { transplantation }\end{array}$ & $\begin{array}{l}6 \text { Months after } \\
\text { transplantation }\end{array}$ & $\begin{array}{l}12 \text { Months } \\
\text { after } \\
\text { transplantation }\end{array}$ & $\begin{array}{l}18 \text { Months } \\
\text { after } \\
\text { transplantation }\end{array}$ & $\begin{array}{l}24 \text { Months } \\
\text { after } \\
\text { transplantation }\end{array}$ \\
\hline \multicolumn{7}{|l|}{ Patient 1} \\
\hline $\begin{array}{l}\text { Sensory } \\
\text { status (LTR } \\
\text { or PPR) }\end{array}$ & 33 & 33 & 33 & 33 & 33 & 33 \\
\hline $\begin{array}{l}\text { Sensory } \\
\text { status (LTL or } \\
\text { PPL) }\end{array}$ & 33 & 33 & 33 & 33 & 33 & 33 \\
\hline $\begin{array}{l}\text { Motor status } \\
\text { (LER) }\end{array}$ & 0 & 0 & 0 & 0 & 0 & 0 \\
\hline $\begin{array}{l}\text { Motor status } \\
\text { (LEL) }\end{array}$ & 0 & 0 & 0 & 0 & 0 & 0 \\
\hline DAP & $\mathrm{N}$ & $\mathrm{N}$ & $\mathrm{N}$ & $\mathrm{N}$ & $\mathrm{N}$ & $\mathrm{N}$ \\
\hline VAC & $\mathrm{N}$ & $\mathrm{N}$ & $\mathrm{N}$ & $\mathrm{N}$ & $\mathrm{N}$ & $\mathrm{N}$ \\
\hline AIS & A & $A$ & A & $A$ & $A$ & $A$ \\
\hline SCIM & 71 & 71 & 71 & 71 & 71 & 71 \\
\hline \multicolumn{7}{|l|}{ Patient 2} \\
\hline $\begin{array}{l}\text { Sensory } \\
\text { status (LTR } \\
\text { or PPR) }\end{array}$ & 37 & 37 & 39 & 44 & 46 & 46 \\
\hline $\begin{array}{l}\text { Sensory } \\
\text { status (LTL or } \\
\text { PPL) }\end{array}$ & 37 & 37 & 39 & 44 & 46 & 46 \\
\hline $\begin{array}{l}\text { Motor status } \\
\text { (LER) }\end{array}$ & 0 & 0 & 0 & 0 & 0 & 0 \\
\hline $\begin{array}{l}\text { Motor status } \\
\text { (LEL) }\end{array}$ & 0 & 0 & 0 & 0 & 0 & 0 \\
\hline DAP & $\mathrm{N}$ & $\mathrm{N}$ & $\mathrm{N}$ & Y & Y & Y \\
\hline VAC & $\mathrm{N}$ & $\mathrm{N}$ & $\mathrm{N}$ & $\mathrm{N}$ & $\mathrm{N}$ & $\mathrm{N}$ \\
\hline AIS & $A$ & $A$ & $A$ & B & B & B \\
\hline SCIM & 33 & 33 & 35 & 39 & 39 & 39 \\
\hline \multicolumn{7}{|l|}{ Patient 3} \\
\hline $\begin{array}{l}\text { Sensory } \\
\text { status (LTR } \\
\text { or PPR) }\end{array}$ & 38 & 38 & 38 & 40 & 40 & 40 \\
\hline $\begin{array}{l}\text { Sensory } \\
\text { status (LTL or } \\
\text { PPL) }\end{array}$ & 38 & 38 & 38 & 40 & 40 & 40 \\
\hline $\begin{array}{l}\text { Motor status } \\
\text { (LER) }\end{array}$ & 0 & 0 & 0 & 0 & 0 & 0 \\
\hline $\begin{array}{l}\text { Motor status } \\
\text { (LEL) }\end{array}$ & 0 & 0 & 0 & 0 & 0 & 0 \\
\hline DAP & $\mathrm{N}$ & $\mathrm{N}$ & $\mathrm{N}$ & $\mathrm{N}$ & $\mathrm{N}$ & $\mathrm{N}$ \\
\hline VAC & $\mathrm{N}$ & $N$ & $\mathrm{~N}$ & $\mathrm{~N}$ & $\mathrm{~N}$ & $\mathrm{~N}$ \\
\hline AIS & $A$ & $A$ & $A$ & $A$ & $A$ & $A$ \\
\hline
\end{tabular}


Abbreviations: LTR, light touch (right); LTL, light touch (left); PPR, pin prick (right); PPL, pin prick (left); LER, lower extremity (right); LEL, lower extremity (left); DAP, deep anal pressure; VAC, voluntary anal contraction; AIS, ASIA impairment scale; SCIM, spinal cord independence measure; $\mathrm{N}, \mathrm{no} ; \mathrm{Y}$, yes

Table 4. Subjective changes of the patients during the two years of follow-up period

\begin{tabular}{|c|c|c|c|c|c|c|c|c|c|c|c|c|c|c|c|c|c|c|}
\hline \multicolumn{3}{|c|}{$\begin{array}{l}24 \text { Months } \\
\text { after } \\
\text { transplantation }\end{array}$} & \multicolumn{3}{|c|}{$\begin{array}{l}18 \text { Months } \\
\text { after } \\
\text { transplantation }\end{array}$} & \multicolumn{3}{|c|}{$\begin{array}{l}12 \text { Months } \\
\text { after } \\
\text { transplantation }\end{array}$} & \multicolumn{3}{|c|}{$\begin{array}{l}6 \text { Months after } \\
\text { transplantation }\end{array}$} & \multicolumn{3}{|c|}{$\begin{array}{l}\text { At the time of } \\
\text { transplantation }\end{array}$} & \multicolumn{3}{|c|}{$\begin{array}{l}6 \text { Months } \\
\text { before } \\
\text { transplantation }\end{array}$} & \multirow{2}{*}{$\begin{array}{l}\text { Variable name } \\
\text { Patient } \\
\text { number }\end{array}$} \\
\hline 3 & 2 & 1 & 3 & 2 & 1 & 3 & 2 & 1 & 3 & 2 & 1 & 3 & 2 & 1 & 3 & 2 & 1 & \\
\hline$=$ & $=$ & $=$ & $=$ & $=$ & $=$ & + & + & $=$ & $=$ & $=$ & $=$ & $=$ & $=$ & $=$ & - & - & - & $\begin{array}{l}\text { Feeling of } \\
\text { urination }\end{array}$ \\
\hline$=$ & $=$ & $=$ & $=$ & $=$ & $=$ & $=$ & + & $=$ & $=$ & $=$ & $=$ & $=$ & $=$ & $=$ & - & - & - & $\begin{array}{l}\text { Feeling of } \\
\text { defecation }\end{array}$ \\
\hline$=$ & $=$ & $=$ & $=$ & $=$ & $=$ & $=$ & $=$ & $=$ & $=$ & $=$ & $=$ & $=$ & $=$ & $=$ & - & - & - & $\begin{array}{l}\text { Urinary } \\
\text { retention }\end{array}$ \\
\hline$=$ & $=$ & $=$ & $=$ & $=$ & $=$ & $=$ & $=$ & $=$ & $=$ & $=$ & $=$ & $=$ & $=$ & $=$ & + & + & + & $\begin{array}{l}\text { Urinary } \\
\text { incontinence }\end{array}$ \\
\hline$=$ & $=$ & $=$ & $=$ & $=$ & $=$ & $=$ & $=$ & $=$ & $=$ & $=$ & $=$ & $=$ & $=$ & $=$ & - & + & - & Constipation \\
\hline$=$ & $=$ & $=$ & $=$ & $=$ & $=$ & $=$ & $=$ & $=$ & $=$ & $=$ & $=$ & $=$ & $=$ & $=$ & + & + & + & $\begin{array}{l}\text { Fecal } \\
\text { incontinence }\end{array}$ \\
\hline$=$ & $=$ & $=$ & $=$ & $\uparrow$ & $=$ & $=$ & $=$ & $=$ & $=$ & $\uparrow$ & $=$ & $=$ & $=$ & $=$ & + & + & + & $\begin{array}{l}\text { Trunk } \\
\text { movements }\end{array}$ \\
\hline$=$ & $=$ & $=$ & $\uparrow$ & $\uparrow$ & $=$ & $=$ & + & $=$ & $=$ & $=$ & $=$ & $=$ & $=$ & $=$ & + & - & + & $\begin{array}{l}\text { Equilibrium } \\
\text { in sitting } \\
\text { position }\end{array}$ \\
\hline$\uparrow$ & + & $=$ & $\uparrow$ & $=$ & $=$ & $=$ & $=$ & $=$ & $=$ & $=$ & $=$ & $=$ & $=$ & $=$ & + & - & + & $\begin{array}{l}\text { Equilibrium } \\
\text { in standing } \\
\text { position }\end{array}$ \\
\hline
\end{tabular}

+ : Present at the time of evaluation

$\therefore$ Absent at the time of evaluation

$=:$ Unchanged compared to the previous evaluation

$\uparrow:$ Increased compared to the previous evaluation

\section{Figures}



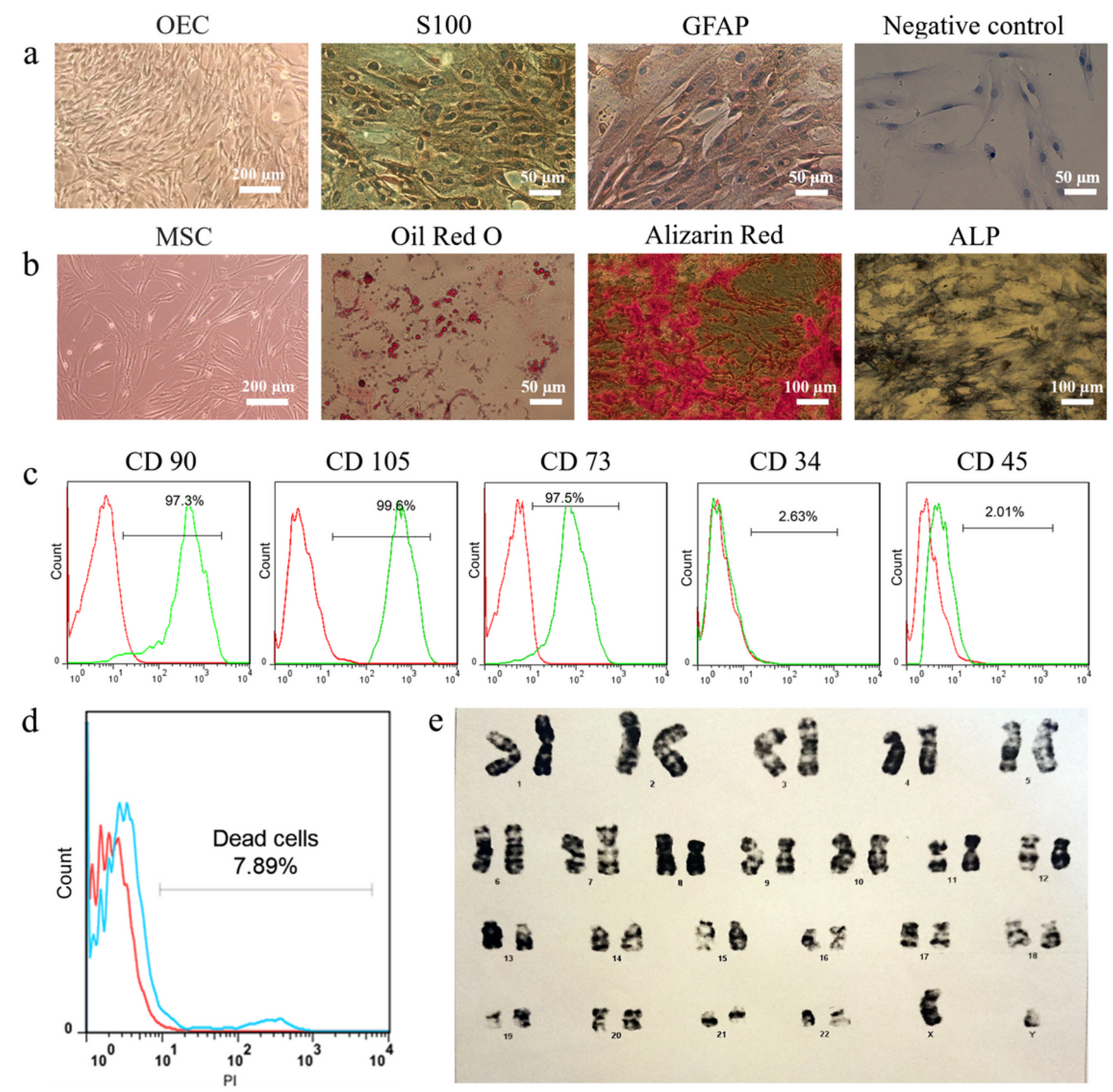

e

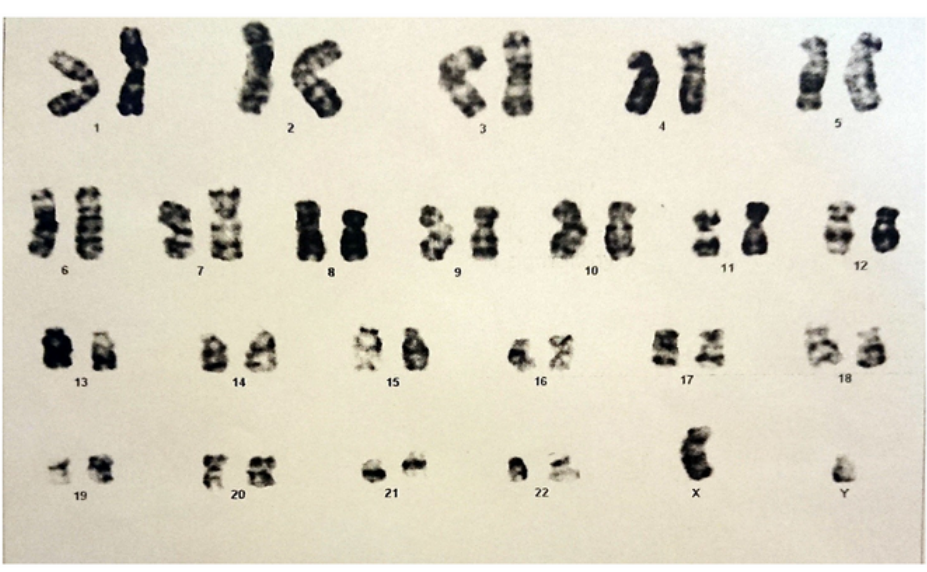

\section{Figure 1}

The quality control test results of the cultured cells. a) The cultured OECs exhibited a normal bi- or multipolar morphology with long processes. The ICC analysis of these cells using DAB showed positive brown staining for S-100 and GFAP identification markers, and the specificity of the results was confirmed by a negative control. b) MSCs preserved their adherent, fibroblast-like appearance during the culture. The adipogenic and osteoblastic differentiation capacity of the isolated cells was demonstrated through oil red o, alizarin red, and alkaline phosphatase staining. c) The bone marrow-derived cells were positive for CD73, CD90, and CD105 and negative for CD34 and CD45 markers using flow cytometry, which is in line with MSC properties. d) The PI viability assessment of the OEC/MSC mixture revealed $92 \%$ alive cells for transplantation. e) No chromosomal anomaly was detected in karyotype examination of the cells by the conventional GTG-banding method. Abbreviations: ICC, immunocytochemical staining; GFAP, glial fibrillary acidic protein; DAB, 3, 3'-diaminobenzidine; OEC, olfactory ensheathing cell; MSC, mesenchymal stem cell; PI, propidium iodide; ALP, alkaline phosphatase 

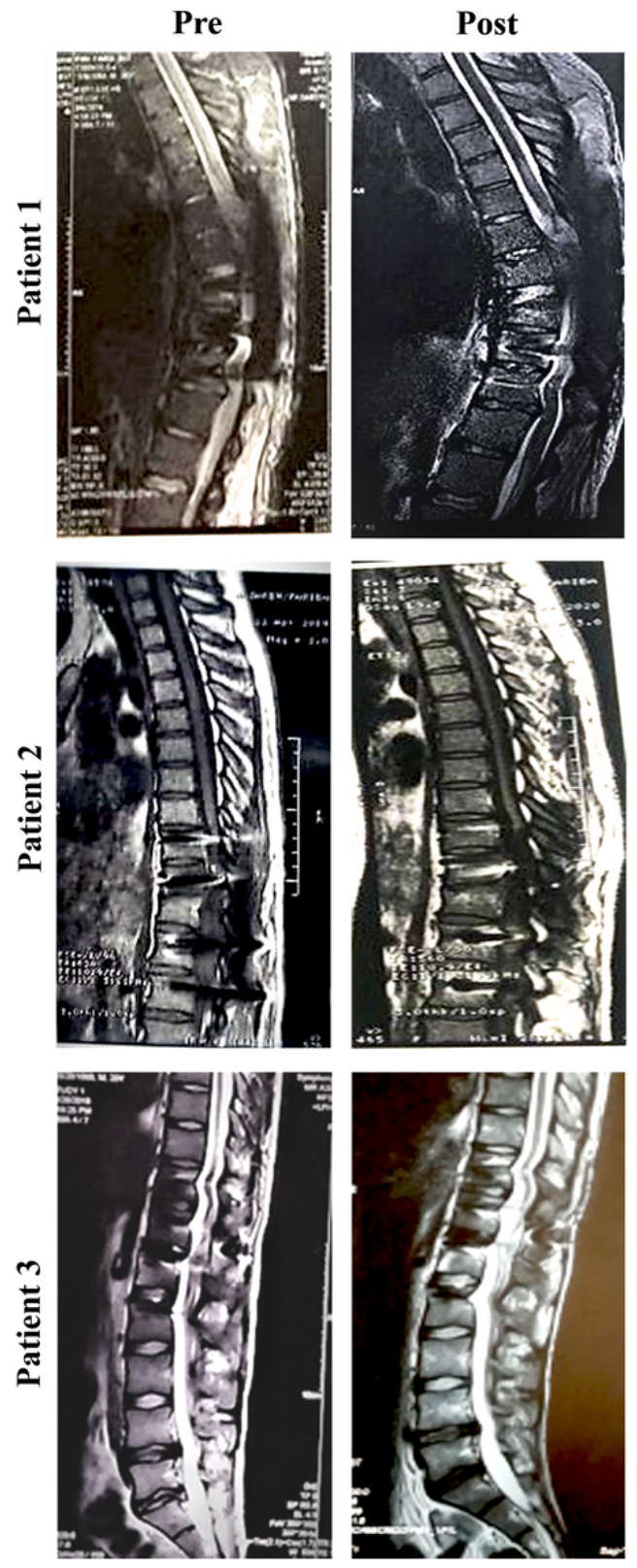

Figure 2

MRI studies of the injured spinal cord before and 24 months after cell transplantation. No tumor tissue, pseudomeningocele, or syringomyelia was detected during the follow-up period. Abbreviations: MRI, magnetic resonance imaging 